\title{
Moderately Differentiated Ovarian Sertoli-Leydig Cell Tumor, Variant with Heterologous Elements
}

National Cancer Institute

\section{Source}

National Cancer Institute. Moderately Differentiated Ovarian Sertoli-Leydig Cell Tumor,

Variant with Heterologous Elements. NCI Thesaurus. Code C39972.

An ovarian Sertoli-Leydig cell tumor of intermediate differentiation, characterized by the presence of a heterologous component, usually consisting of cartilage, skeletal muscle, or rhabdomyosarcoma. 